\title{
The complex microbiome in aquaponics: significance of the bacterial ecosystem
}

\author{
Nasser Kasozi ${ }^{1,2}$, Benjamin Abraham ${ }^{1}$, Horst Kaiser $^{3}$ and Brendan Wilhelmi ${ }^{*}$ (D)
}

\begin{abstract}
Purpose: Aquaponics is a technology that has minimal impact on the environment and which is often promoted as a solution for sustainable food production. Developing aquaponics sustainably requires a thorough understanding of the biological components of the system. Recent reports on the bacterial populations of aquaponics systems using new DNA sequencing technologies are revealing a complex and diverse microbial ecosystem. The purpose of this review is to present information on microbial composition and various factors affecting bacterial activity in aquaponics systems. Approaches for establishing a bacterial ecosystem during the setup of an aquaponics system, and microbiological safety of aquaponics products are also highlighted.

Methods: This review was developed by evaluating and synthesising current literature of peer-reviewed publications related to aquaponics and microbial communities. Based on the results from credible academic journals, publications were categorised into five groups: methods used to characterise microbiomes, biofiltration microorganisms, bacterial diversity, biofilter establishment, and safety of aquaponics products.
\end{abstract}

Results: The microbial ecosystem is essential for biological filtration of water through the mineralisation of nutrients required for plant growth in an integrated system. The aquaponics microbiome is complex, and bacterial composition varies between the different compartments of these systems. Establishing these bacterial ecosystems is essential for optimal functioning of aquaponics. At the phylum level, Proteobacteria and Bacteroidetes are dominant in aquaponics systems. Despite bacteria being fundamental to aquaponics, there are currently no reports of human pathogens in aquaponics products.

Conclusion: Knowledge of the composition of bacterial populations in aquaponics systems will enhance understanding of relationships and functions within the microbiome. This in turn will allow for the establishment of sustainable and healthy aquaponics systems for food production.

Keywords: Aquaponics system, Fish, Microbial communities, Microbial diversity

\section{Introduction}

Human population growth worldwide has led to research into new agricultural systems to meet the increasing demand for food (Fedoroff et al. 2010; Molden 2007). For example, systems that integrate plants with fish production are recognised as environmentally friendly and sustainable (Rakocy et al. 2006). Aquaponics involves combining fish and soilless plant production,

\footnotetext{
* Correspondence: b.wilhelmi@ru.ac.za

${ }^{1}$ Department of Biochemistry and Microbiology, Rhodes University, P.O. Box 94, Makhanda, Grahamstown 6140, South Africa

Full list of author information is available at the end of the article
}

either in a single process loop (coupled) or a two-loop (decoupled) design (Goddek et al. 2019; Love et al. 2015; Rakocy et al. 2006). The advantage of aquaponics over recirculating aquaculture systems (RASs) and hydroponic systems include the capability of raising fish, while simultaneously growing edible plants, which remove nutrients from the water (Tyson et al. 2011). Thus, the system allows for the continuous production of quality fish and vegetables while minimising water replacement. In addition, there is a reduced need for formulated fertilisers (Rakocy et al. 2006; Wongkiew et al. 2017).

(c) The Author(s). 2021 Open Access This article is licensed under a Creative Commons Attribution 4.0 International License, which permits use, sharing, adaptation, distribution and reproduction in any medium or format, as long as you give appropriate credit to the original author(s) and the source, provide a link to the Creative Commons licence, and indicate if changes were made. The images or other third party material in this article are included in the article's Creative Commons licence, unless indicated otherwise in a credit line to the material. If material is not included in the article's Creative Commons licence and your intended use is not permitted by statutory regulation or exceeds the permitted use, you will need to obtain permission directly from the copyright holder. To view a copy of this licence, visit http://creativecommons.org/licenses/by/4.0/. 
A feature of aquaponics is the reliance on the bacterial ecosystem. Most fish species retain $20-30 \%$ of ingested dietary nitrogen (Schreier et al. 2010), and $70-80 \%$ is released into the water as waste (Krom et al. 1995). Digested protein is excreted mostly as ammonium $\left(\mathrm{NH}_{4}^{+}\right)$through the gills (Tyson et al. 2011; Wongkiew et al. 2017). $\mathrm{NH}_{4}{ }^{+}$can also accumulate because of bacterial decomposition of organic matter such as protein and nitrogenous compounds in uneaten feed (Roosta and Hamidpour 2011). Ammonium nitrogen $\left(\mathrm{NH}_{4}{ }^{+}-\mathrm{N}\right)$ excreted by fish provides the major form of nitrogen essential for plant growth (Roosta and Hamidpour 2011; Wongkiew et al. 2017). Biological nitrification of the nutrient-rich fish tank water forms nitrate $\left(\mathrm{NO}_{3}{ }^{-}\right)$which is assimilated by plants (Tyson et al. 2011). Nitrification converts $\mathrm{NH}_{4}{ }^{+}$, which becomes harmful to fish at increasing $\mathrm{pH}$, to $\mathrm{NO}_{3}{ }^{-}$, thereby maintaining water quality. In addition, in weakly buffered water, nitrification can decrease the $\mathrm{pH}$ value of the system water, while bacterial denitrification can increase water $\mathrm{pH}$. Therefore, the composition of the bacterial ecosystem is essential to aquaponics farming (Rakocy et al. 2006; Wongkiew et al. 2017).

Comprehensive reviews on the relative distribution of microorganisms have been published in the context of RASs and with emphasis on these systems' biofiltration (Rurangwa and Verdegem 2015; Schreier et al. 2010). However, those reviews only considered recirculating systems without plants. In addition, aquaponics systems include a hydroponic unit (gravel media beds and/or deep-water culture rafts) and may include an additional sump and water treatment systems. These more complex systems potentially have more diverse microbial communities, with the microbiome in the different compartments likely to differ. Knowledge of the microbial diversity and functional distribution of these microorganisms in aquaponics systems is key to understanding microbial community dynamics and to enhance system performance (Bartelme et al. 2018, 2019; MunguiaFragozo et al. 2015; Schmautz et al. 2017).

Therefore, we focused on reviewing literature that deals specifically with the bacterial dynamics in aquaponics systems in order to contribute to our understanding of this emerging technology. This review considers the complexity of the aquaponics microbiome by providing a description of the bacterial communities. Such information can assist in understanding the microbial ecology and in improving the management of these ecosystems.

\section{Methods for the characterisation of microbial communities}

Traditionally, direct and indirect counting of cells have been the most common methods for the enumeration of bacteria. Although these methods are inexpensive, culturing high levels of bacterial and fungal species with these techniques is limited (Biswas and Sarkar 2018). The development of multi-"omics" technologies has provided very powerful tools for the analysis of complex ecosystems. These techniques include marker gene analysis, shotgun metagenomics, metatranscriptomics, metaproteomics, and metabolomics, which have been used to generate information on the microbial community structure and function in soil samples. More recently, metagenomics has been used for the analysis of aquaponics samples (Joyce et al. 2019; Munguia-Fragozo et al. 2015).

Targeted sequencing methods are revolutionising research for studying microbial communities in aquaponics. Environmental DNA sampling and meta-barcoding analysis is a relatively new approach for determining bacterial populations in aquaponics (Eck et al. 2019; Thomsen and Willerslev 2015; Kasozi et al. 2020). These sequencing methods include $16 \mathrm{~S}$ ribosomal RNA (rRNA) gene and internal transcribed spacer (ITS) used to identify bacteria and fungi, respectively, in a given environmental sample (Galloway-Pena and Hanson 2020). This approach allows for comprehensive insights into the microbial diversity of mature, healthy aquaponics systems, as well as the identification of potential pathogens in sub-optimal systems. This will potentially allow aquaponics farmers to add beneficial microbial cocktails or biological control treatments to ensure healthy ecosystems for enhanced and safe food production (Sirakov et al. 2016).

Recent studies are applying shotgun metagenomics to explore microbial communities in terms of diversity and function (Shakya et al. 2019). Metatranscriptomics provides the diversity of the active genes in a complex microbial community and enables understanding on how the microbiome responds to the environment (Galloway-Pena and Hanson 2020). With aquaponics, metatranscriptomics may be useful in the characterisation of genes involved in organic matter degradation. Other rapidly emerging technologies that use mass spectrometry for studying the microbiome include metabolomics and metaproteomics. Through metabolomics, comprehensive coverage of a large number of small-molecule metabolites in microbial communities can be profiled under a given set of conditions (Wang et al. 2020) while metaproteomics focuses on identifying and quantifying proteins expressed by the microbial community (Biswas and Sarkar 2018; Shulaev 2016). Metabolomics has already been applied in many biological studies involving environmental interactions, functional genomics, and gene discovery, although not yet in aquaponics.

\section{Biofiltration in aquaponics}

Bacteria are fundamental in the maintenance of an aquaponics ecosystem (Eck et al. 2019; Schmautz et al. 2017). 
Aquaponics systems contain autotrophic and heterotrophic bacteria (Blancheton et al. 2013; Eck et al. 2019), with spatial distribution being a function of environmental conditions, such as levels of oxygen and nutrient availability (Munguia-Fragozo et al. 2015). Fish tank and biological filters in aquaponics systems are similar to RASs in their design as they aim at enhancing oxidation of both total ammonia nitrogen (TAN) and nitrite $\left(\mathrm{NO}_{2}{ }^{-}\right)$. Therefore, the same nitrifying and denitrifying microorganisms are likely to exist in both systems. However, differences are likely to be seen in the species distribution between parts of the fish rearing section and the hydroponics units (Wongkiew et al. 2017). Microorganisms are found in every compartment of aquaponics systems. However, studies characterising microbial composition and structure in different parts of aquaponics systems are limited. Recent research on microbial characterisation has focused on bacterial diversity in periphyton, plant roots, biofilter, and fish faeces (Schmautz et al. 2017) and media grow bed zones (Kasozi et al. 2020). Thus, there is still a need for characterisation of aquaponics microbial communities related to fish (fish intestines and fish feed) and plants (rhizosphere, phyllosphere, and fruit surface). Microorganisms in aquaponics systems are involved in multiple processes, including nitrification, organic matter decomposition, denitrification, phosphorus mineralisation, and iron cycling (Table 1).

If bacterial diversity is not balanced or operational conditions are not suitable for bacterial metabolism, the water quality in the aquaponics system may fluctuate, creating a harmful environment for fish and plants. Some authors have listed bacterial populations in the compartments of aquaponics systems (Eck et al. 2019;
Schmautz et al. 2017; Wongkiew et al. 2018). In addition to heterotrophic and nitrifying bacteria, Table 2 presents other bacterial groups linked to the nitrogen cycle. Bacterial groups in freshwater aquaponics systems include Actinobacteria, Proteobacteria, Bacteroidetes, Nitrospirae, Fusobacteria, Planctomycetes, and Chloroflexi (Table 2).

In addition, these studies indicated that there are micro-niches that support the development of specific microbial populations (Rurangwa and Verdegem 2015). Because different fish species will introduce unique microbial flora, microbial diversity varies between systems. Molecular techniques have been used to identify the microbial communities in aquaponics compartments and substrates and to predict their possible effects on plant growth and health (Eck et al. 2019; Schmautz et al. 2017).

Eck et al. (2019) and Schmautz et al. (2017) collected samples from several aquaponics compartments and characterised the bacteria with meta-barcoding techniques. Their major findings were that in most samples, the phyla Proteobacteria and Bacteroidetes were dominant. The study reported by Eck et al. (2019) indicated that Proteobacteria and Bacteroidetes accounted for $34.6 \%$ and $25.5 \%$ of the total bacterial community, respectively, from the 22 samples collected from various aquaponics and aquaculture systems. Schmautz et al. (2017) reported that $46.7 \%$ of the total biofilter bacterial community was assigned to Proteobacteria, while Bacteroidetes accounted for $17.5 \%$ of the total lettuce root bacterial community.

At the genus level, the biofilter samples contained relatively high abundance of Nitrospira $3.9 \%$ of total

Table 1 Major microbiological processes and contributing microorganisms in aquaponics systems

\begin{tabular}{|c|c|c|}
\hline Microbiological process & Genera & Reference \\
\hline \multicolumn{3}{|l|}{ Nitrification } \\
\hline Ammonia oxidisation & $\begin{array}{l}\text { Nitrosomonas, Nitrosococcus, Nitrosospira, } \\
\text { Nitrosolobus, Nitrosovibrio }\end{array}$ & $\begin{array}{l}\text { Ebeling et al. (2006); Rurangwa and Verdegem (2015); } \\
\text { Schreier et al. (2010); Schmautz et al. (2017) }\end{array}$ \\
\hline Ammonia oxidisation by archaea & Trosopumilus, Nitrososphaeras & Bartelme et al. (2019) \\
\hline Nitrite oxidation & Nitrobacter, Nitrospira, Nitrococcus, Nitrospina & $\begin{array}{l}\text { Ebeling et al. (2006); Schmautz et al. (2017); } \\
\text { Wongkiew et al. (2018) }\end{array}$ \\
\hline Complete ammonia oxidation & Nitrospira & Daims et al. (2015); Bartelme et al. (2019) \\
\hline Denitrification & Dokdonella, Thermomonas & Schmautz et al. (2017) \\
\hline Mineralisation & $\begin{array}{l}\text { Pseudomonas, Flavobacterium, } \\
\text { Sphingobacterium, Arcobacter }\end{array}$ & Eck et al. (2019); Wongkiew et al. (2018) \\
\hline $\begin{array}{l}\text { Anaerobic ammonium } \\
\text { oxidation (Anammox) }\end{array}$ & Brocadia & Schmautz et al. (2017) \\
\hline Sulphate reduction & $\begin{array}{l}\text { Fusibacter, Bacteroides, Desulfovibrio, } \\
\text { Dethiosulfovibrio }\end{array}$ & Schreier et al. (2010); Somerville et al. (2014) \\
\hline Organic phosphorus mineralisation & Modestobacter & Kasozi et al. (2020) \\
\hline Iron cycling & Acidibacter & Kasozi et al. (2020) \\
\hline Nitrogen fixation & Pontibacter, Pseudonocardia & Kasozi et al. (2020) \\
\hline
\end{tabular}


Table 2 Prominent taxa identified from different compartments of aquaponics systems

\begin{tabular}{lll}
\hline $\begin{array}{l}\text { Aquaponics compartment/ } \\
\text { source/substrate }\end{array}$ & Predominant taxa (phyla/family/order/genera) & Reference \\
\hline Sump & $\begin{array}{l}\text { Rhizobiaceae, Sphingomonas spp., Devosia spp., Novosphingobium spp., } \\
\text { Acidovorax spp., Ralstonia spp., and Deinoccoccus spp. }\end{array}$ & Eck et al. (2019) \\
Fish faeces & Fusobacteria, Bacteroidetes, Firmicutes, Proteobacteria, Enterobacteriales, & Schmautz et al. (2017) \\
& Cetobacterium spp., Plesiomonas spp. & Hu et al. (2015); Schmautz et al. \\
Plant roots & Proteobacteria, Planctomycetes, Acidobacteria, Bacteroidetes, Nitrospirae, & Eck et al. (2019); \\
Biofilter & Gemmatimonadetes, Methylophilales, Nitrosomonadales, and Pseudomonas spp. (2017); Wongkiew et al. (2018) \\
& Bacteroidetes, Verrucomicrobia, Fusobacteria, Planctomycetes, & Wongkiew et al. (2018) \\
Periphyton in fish rearing tanks & Chloroflexi, Nitrospirae, Proteobacteria, Microbacteriaceae, Rhodobacterales, \\
Fish tank effluent & Xanthomonadales, Rhizobiales, Dokdonella spp., Thermomonas spp. & Schmautz et al. (2017) \\
\hline
\end{tabular}

community), and low abundances in the periphyton $(0.14 \%)$ and lettuce roots $(0.08 \%)$. In samples from fish faeces, Cetobacterium and Plesiomonas constituted $73.8 \%$ and $3.0 \%$ of the total bacterial community, respectively. Furthermore, Schmautz et al. (2017) reported that the periphyton contained relatively high abundance of Dokdonella and Thermomonas, which constituted $7.61 \%$ and $1.82 \%$ of the total bacterial, respectively.

\section{Biofilter establishment}

Biofilter establishment or cycling, a process of building bacterial ecosystems during the setup of an aquaponics system, can be done with or without the presence of fish in the system (Brailo et al. 2019; DeLong and Losordo 2012; Sallenave 2016).

\section{Fish cycling}

This approach recommends the use of low fish stocking densities, and the initial administration of low amounts of feed to prevent a rapid build-up of TAN, which is harmful to fish (DeLong and Losordo 2012; Sallenave 2016). As the biofilter establishes, fish density can be incrementally increased, and feed levels adjusted appropriately (Brailo et al. 2019). Cycling with fish can take up to 6 weeks for bacterial populations to establish (Sallenave 2016). TAN and $\mathrm{NO}_{2}{ }^{-}$levels should be measured daily during this process. Once $\mathrm{NO}_{3}{ }^{-}$is detected in the system and the TAN and $\mathrm{NO}_{2}{ }^{-}$are below $0.5 \mathrm{mg} \mathrm{L}^{-1}$, the system is ready for plant cultivation (Sallenave 2016).

\section{Cycling with ammonia compounds}

This is the most commonly used quick method for biofilter establishment (Brailo et al. 2019; Sallenave 2016). In this case, ammonia is added to the system, which allows nitrifying bacteria to establish in response to the availability of these inorganic nutrients, while organic compound levels that may enhance the growth of the faster growing heterotrophs are still low. Thus, this method requires less time to establish the biofilter, i.e. approximately 3 weeks (Sallenave 2016). This method permits control of how much ammonia is added, creating better water quality, which improves fish health, growth, and survival (DeLong and Losordo 2012). As with the fish cycling method, as soon as TAN and $\mathrm{NO}_{2}{ }^{-}$ levels drop to near zero and a measurable level of $\mathrm{NO}_{3}{ }^{-}$ is reached, the system is considered fully cycled and ready for fish. Ammonia supplementation should be stopped once fish are added because the $\mathrm{NH}_{4}{ }^{+}$is now produced by the fish. Chemical compounds such as $\mathrm{NH}_{3}, \mathrm{NH}_{4} \mathrm{Cl}, \mathrm{NH}_{4} \mathrm{NO}_{2}$, or organic fertilisers with $\mathrm{NH}_{4}{ }^{+}$ are added to an aquaponics system to achieve "fishless cycling" at a dosage that raises the TAN levels to between 3 and $5 \mathrm{mg} \mathrm{L}^{-1}$ (Sallenave 2016). Urea can also be used as a nitrogen source. Bacteria convert urea to $\mathrm{NH}_{4}{ }^{+} / \mathrm{NH}_{3}$ as part of the nitrogen cycle through regulation of urease activity (Solomon et al. 2010). In addition, some bacteria can also use urea amidolyase to decompose urea to $\mathrm{NH}_{4}{ }^{+}$(Solomon et al. 2010).

At a practical level, aquaponics farmers typically do not have a direct method for assessing the microbial populations in their systems. The establishment of a functional microbial ecosystem is measured indirectly through monitoring $\mathrm{pH}$, as well as $\mathrm{NH}_{4}{ }^{+}, \mathrm{NO}_{2}{ }^{-}$, and $\mathrm{NO}_{3}{ }^{-}$levels. A decrease in $\mathrm{NH}_{4}{ }^{+}$and $\mathrm{NO}_{2}{ }^{-}$levels $(<0.5$ $\mathrm{mg} \mathrm{L}^{-1}$ ) and stable $\mathrm{NO}_{3}{ }^{-}$levels are used as indicators of microbial activity. The bioconversion of $\mathrm{NH}_{4}{ }^{+}$to $\mathrm{NO}_{3}{ }^{-}$ decreases water $\mathrm{pH}$, which is typically adjusted using sodium bicarbonate and potassium or calcium hydroxide.

\section{Nitrifying bacteria}

Environmental nitrifying bacteria have been intensively studied (Munguia-Fragozo et al. 2015). The main role of these bacteria is to transform $\mathrm{NH}_{4}{ }^{+}$and $\mathrm{NH}_{3}$ excreted by the fish or derived from organic material into $\mathrm{NO}_{2}{ }^{-}$ and then $\mathrm{NO}_{3}{ }^{-}$, the latter being relatively less toxic to fish than ammonia and nitrite. In aquaponics, nitrifying bacteria are commonly found in the biological filter or on any other substrates that allow colonisation. In 
systems with hydroponic media beds, the inert media can also provide a habitat for the bacteria and biological filtration (Somerville et al. 2014).

The nitrification process is conducted by three distinct groups of microorganisms based on the biochemistry involved (Daims et al. 2015; Holmes et al. 2019; Stein and Klotz 2016). The first group includes bacteria that oxidise $\mathrm{NH}_{4}{ }^{+}$and $\mathrm{NH}_{3}$ to $\mathrm{NO}_{2}^{-}$through a process termed nitritation. The second group comprises of microorganisms that oxidise $\mathrm{NO}_{2}^{-}$to $\mathrm{NO}_{3}{ }^{-}$through a process of nitratation, and bacteria in the third group oxidise $\mathrm{NH}_{4}{ }^{+}$ to $\mathrm{NO}_{3}{ }^{-}$(Comammox). Bacteria of the genera Nitrosomonas, Nitrosococcus, Nitrosospira, Nitrosolobus, and Nitrosovibrio are involved in the first stage of nitrification. The second group includes the genera Nitrobacter, Nitrococcus, Nitrospira, and Nitrospina (Hagopian and Riley 1998). The third group is from lineage II of Nitrospira (Daims et al. 2015). These bacteria are chemoautotrophs, using $\mathrm{NH}_{4}{ }^{+}$as an energy source for carbon dioxide fixation and oxygen as a final electron acceptor (Hagopian and Riley 1998). Nitrifying bacteria form a consummate relationship with "heterotrophic bacteria, protozoa and micrometazoa", which degrade biological compounds in the biofilter components (Rurangwa and Verdegem 2015).

In addition to the cohorts discussed above, anaerobic ammonium oxidation (Anammox) and heterotrophic ammonia-oxidising bacteria (HAOB) have been reported in biofilters within freshwater aquaculture systems, as well as from sediments of marine, freshwater, and agricultural origin. Anammox bacteria oxidise $\mathrm{NH}_{4}{ }^{+}$using $\mathrm{NO}_{2}{ }^{-}$as electron acceptor and form gaseous nitrogen as an end-product, while the HAOB oxidation pathway involves $\mathrm{NH}_{4}{ }^{+}$being oxidised by ammonia monooxygenase to hydroxylamine, which is then oxidised to $\mathrm{NO}_{2}{ }^{-}$by a hydroxylamine-quinone reductase (Holmes et al. 2019; Zou et al. 2016).

\section{Denitrifying bacteria}

Denitrification may lead to more than a $50 \%$ loss of total nitrogen available in an aquaponics system $(\mathrm{Hu}$ et al. 2015; van Rijn et al. 2006; Zou et al. 2016). In anoxic environments, denitrifying bacteria transform $\mathrm{NO}_{3}{ }^{-}$to nitrogen gas $\left(\mathrm{N}_{2}\right)$. Different microorganisms possess complete, partial, or no denitrification activities (Holmes et al. 2019; Lu et al. 2014). Incomplete denitrifying microorganisms lack the $\mathrm{NO}_{2}{ }^{-}$reductase enzyme, which enables complete denitrification (Holmes et al. 2019). Denitrifying bacteria include Achromobacter, Aerobacter, Acinetobacter, Bacillus, Brevibacterium, Flavobacterium, Pseudomonas, Proteus, and Micrococcus spp. (Holmes et al. 2019; Lu et al. 2014; Zumft 1997). These microorganisms use nitrate as the electron acceptor, and dissolved organic carbon as the electron donor, with denitrification rates dependent on the carbon source. $\mathrm{Hu}$ et al. (2015) reported nitrogen loss $\left(\mathrm{NH}_{3}, \mathrm{~N}_{2} \mathrm{O}\right.$, and $\left.\mathrm{N}_{2}\right)$ of $51.2 \%$ in tomato and $57.3 \%$ in pak choi aquaponics systems, although gaseous loss of $\mathrm{NH}_{3}$ and $\mathrm{N}_{2} \mathrm{O}$ were negligible relative to $\mathrm{N}_{2}$ emission. Aquaponics systems may have pockets of anoxic zones, for example in the mineralised zones of gravel media beds; these may provide favourable conditions for the occurrence of denitrification (Kasozi et al. 2020).

The processes of nitrification and denitrification occurring simultaneously have been shown in soil-based environments, AOB from either the genus Nitrosospira or Nitrosomonas have been reported to perform denitrification (Pajares and Bohannan 2016; Shaw et al. 2006), although this has not been reported in aquaponics.

\section{Heterotrophic bacteria}

Heterotrophic bacteria utilise organic matter such as carbohydrates, amino acids, peptides, and lipids as carbon and energy sources (Munguia-Fragozo et al. 2015; Stouvenakers et al. 2019). Although they colonise all components of the aquaponics system, they are particularly concentrated in areas where solid waste accumulates (Joyce et al. 2019). Because nitrifying and heterotrophic bacteria are aerobic, they compete for oxygen, and although heterotrophic bacteria are essential for efficient aquaponics systems, they can have a negative effect on biofiltration at high total carbon levels (Rurangwa and Verdegem 2015). The ratio of total organic carbon to $\mathrm{NH}_{4}{ }^{+}$, and dissolved oxygen in the water, are therefore important factors in balancing the microbial ecology (Aoi et al. 2000; Hagopian and Riley 1998).

Heterotrophic bacterial metabolism mineralises the solid waste, thereby providing soluble micronutrients for the plants in aquaponics systems. Bacteria of the genera Flavobacterium and Sphingobacterium have been postulated to decompose organic matter in aquaponics (Eck et al. 2019). Other roles such as the transformation of insoluble phytates into phosphorus by Proteobacteria need more investigation in aquaponics systems.

\section{The rhizosphere microorganisms}

Microorganisms also extract macro- and micronutrients from uneaten feed and faecal matter and increase their bioavailability to plants (Goddek et al. 2016). Various types of microorganisms stimulate root growth and nutrient acquisition from soil (Richardson et al. 2009). Sanchez et al. (2019) identified plant growth promoting bacteria (PGPB) isolated from tilapia-rearing water from a RAS. These PGPB include bacteria from the phyla Proteobacteria, Actinobacteria, and Firmicutes. The interactions between plants and microorganisms depend on 
chemical signalling, which may occur in a specific or a generalised manner (Chagas et al. 2018).

Root health is essential for plant health and survival and to the composition of microbial populations proximate to the root surface (Chagas et al. 2018). A $16 \mathrm{~S}$ rRNA meta-barcoding study of lettuce roots by Schmautz et al. (2017) revealed the genera Acidovorax, Sphingobium, Flavobacterium, and Pseudomonas in an aquaponics system integrated with Oreochromis niloticus and lettuce. However, the role of these bacteria on roots, including the effect of root exudates in aquaponics systems, is not yet known. Nevertheless, findings reported from research in traditional soil-based agriculture indicate that plant roots produce, accumulate and release an array of compounds, including organic acids, phenolics, nucleotides, carbohydrates, putrescine, sterols, and vitamins (Chagas et al. 2018; Michalet et al. 2013). Secreted compounds can act as both chemical attractants and repellents for microorganisms (Kawasaki et al. 2016). This could provide the plant with access to beneficial symbiotic microorganisms, and protection from potentially harmful bacteria.

Some rhizosphere microbes, for example Bacillus amyloliquefaciens and Pseudomonas fluorescens, possess gene clusters for detoxification, as well as antibiotic and siderophore synthesis (Lareen et al. 2016; Paulsen et al. 2005). This is further supported by the research of Schmautz et al. (2017), who reported a relative abundance of $2.2 \%$ from the genus Pseudomonas from root samples of aquaponics lettuce, which may confer a biocontrol benefit. Compounds which can be produced by Pseudomonas and which have antibiotic activity include 2,4-diacetylphloroglucinol, oomycin A, and phenazine (Lareen et al. 2016). Bacteria also produce secondary products that can affect both plant signalling and metabolism (Lareen et al. 2016).

In agricultural systems, bacteria promote plant growth and health through biofertilisation, root growth, rhizoremediation, and resistance to abiotic stressors (Bartelme et al. 2018; Mendes et al. 2013). These mechanisms have been reported for rhizobacteria of the genera Pseudomonas, Bacillus, Enterobacter, Streptomyces, and fungi of the genera Gliocladium and Trichoderma (da Silva and Fitzsimmons 2016; Lee and Lee 2015; Mendes et al. 2013). Trichoderma spp. improve plant resistance to disease by producing hydrolytic enzymes and antibiotics, and the production of pathogenesis-related proteins (Punja and Utkhede 2003).

\section{Fish and plant pathogens}

A range of fish or plant pathogens can inadvertently be introduced into soilless production systems (Joyce et al. 2019; Stouvenakers et al. 2019). Preventing the introduction and suppressing the growth of pathogens in aquaponics systems is vital as the recycling of water provides a favourable environment for the multiplication of pathogens. Pathogens can enter an aquaponics system through water additions, equipment, fish feed, infected plants or seeds, stocked fish, staff or visitors to the system, and media grow bed aggregates (Mori and Smith 2019; Stouvenakers et al. 2019). In particular, the inflowing water can introduce viral and opportunistic bacterial pathogens (Lee and Lee 2015; Mori and Smith 2019). Fish skin and gastrointestinal tracts, as well as plants, may introduce bacteria to an aquaponics system (Munguia-Fragozo et al. 2015). Aquaponics plants are mostly grown in indoor systems. Pathogens can threaten their viability as these indoor systems are often humid, warm, windless, and rainfree. These conditions can be conducive to diseases if not properly managed (Stouvenakers et al. 2019).

Soil-borne pathogens can be found in aquaponics systems, but pathogens are typically outnumbered and suppressed by non-pathogenic organisms (Lee and Lee 2015). Although pathogens have been reported in aquaponics systems, there is a limited number of reports on transmission mechanisms (Mori and Smith 2019), possibly because of the time required and complexity of such studies (Mehle et al. 2014). However, hydroponicrelated literature indicates that waterborne infection occurs when the pathogen is released from a diseased plant, for example, from the roots of an infected plant. The relative abundance of pathogens in a system is dependent on the rate of pathogen shedding and their viability in solution (Mehle et al. 2014).

A review by Mori and Smith (2019) found no reports of pathogen transmission in aquaponics systems, with information on pathogen transmission in soilless systems only being available from aquaculture and hydroponics studies. Research by Mehle and Ravnikar (2012) demonstrated plant virus survival in water and suggested viral concentration-dependent transmission through the roots of plants. Other studies have highlighted the proliferation of the oomycetes (Phytophthora spp. and Pythium spp.) in aquaponics systems (Lee and Lee 2015; Li et al. 2014; Stouvenakers et al. 2019). These zoosporic organisms are adapted to warm, humid, and windless conditions common in greenhouse structures (Stouvenakers et al. 2019). Additionally, the ability to locate utilisable carbon sources quickly allow zoospores to spread rapidly, particularly in water recycling systems (Hong and Moorman 2005). For example, Pythium spp., because of their mobile form of dispersion, spread through water recirculating systems and cause root rot in hydroponic plants (Lee and Lee 2015). Thus, managing fungal infections in aquaponics operations is vital. Similarly, the number of reports of plant viruses in recirculating nutrient solutions in hydroponic systems is increasing, 
particularly from investigations using next-generation sequencing approaches (Hong and Moorman 2005; Mehle et al. 2014).

The introduction of probiotic bacteria into aquaponics systems is an approach that can be used to inhibit pathogens (Stouvenakers et al. 2019). Probiotic bacteria produce a number of positive effects in aquaculture systems, which include the competition for nutrients such as iron, improvement of water quality, and the production of chemical compounds that inhibit the growth of other microorganisms (Verschuere et al. 2000). Although beneficial bacteria from the genus Bacillus have been used in aquaponics systems, research indicating their effect on plant growth, plant disease control, and nutrient availability is lacking.

\section{Microbiological safety of aquaponics products}

Vegetables grown in aquaponics systems are mostly consumed raw. The World Health Organization (WHO) and the Food and Agriculture Organization (FAO) have prioritised minimising microbial contamination risks of leafy vegetables (FAO/WHO 2008). The WHO guidelines for treated wastewater for agricultural crop irrigation limit faecal coliforms to $<10^{3}$ $100 \mathrm{~mL}^{-1}$ (WHO 1989).

Pathogenic bacteria can be introduced into the food supply chain at pre-harvest, harvest, distribution, and storage stages of production (FAO/WHO 2008; Moriarty et al. 2018; Mori and Smith 2019). Despite good agricultural practices and rigorous post-harvest cleansing, outbreaks of foodborne E. coli O157:H7 from fresh produce have occurred in different agricultural production systems (Mori and Smith 2019; Sivapalasingam et al. 2004). Various coliforms and bacteria in general are present throughout aquaponics systems (Rakocy et al. 2006). However, the microbial safety concerns have been allayed in part by the results of studies that indicate low risk of microbial contamination of the products from aquaponics systems, as compared to products grown in the soil-based systems (Fox et al. 2012; Mori and Smith 2019).

$E$. coli can enter plant tissues through the stomata, through penetration of the junction zones of cut leaves, and transportation through the plant roots (Gomes et al. 2009; Mendes et al. 2013). Infection typically includes attachment to a leaf surface, bacterial congregation, mesophyll cell wall perforation, and penetration through stomata (Plotnikova et al. 2000). Gomes et al. (2009) reported that E. coli pathogenesis of lettuce showed preferred entry through the stomatal cavity. In addition, wounding of the root system has also been reported to increase the incidence of $E$. coli internalisation. Macarisin et al. (2014) reported that the incidence of internalisation of hydroponic spinach was directly proportional to bacterial concentration.

Despite published reports indicating internalisation of human foodborne pathogens in fresh fruit and vegetables, there have been no reports of human pathogens in aquaponics products yet. Numerous studies have demonstrated aquaponics lettuce to have significantly lower microorganism abundance relative to soil-grown equivalents, with no detectable E. coli coliforms, E. coli O157: H7, or Salmonella spp. in the aquaponics lettuce samples (Elumalai et al. 2017; Fox et al. 2012; Moriarty et al. 2018; Sirsat and Neal 2013).

Chitmanat et al. (2015) reported the presence of Aeromonas hydrophila, a bacterial fish pathogen and a suspected human pathogen causing diarrhoea (Daskalov 2006), in aquaponics systems containing catfish, but the authors did not investigate pathogen transmission or its effects on the crops. In addition, Schmautz et al. (2017) reported a low occurrence of Aeromonas ( $0.25 \%$ of the total bacterial community) in the faecal samples of tilapia reared in an aquaponics system that included lettuce growing on a floating raft. Although its effect on the crop was not investigated, the fish were reported as healthy.

\section{Main factors influencing bacterial activity in aquaponics systems}

$\mathrm{pH}$

$\mathrm{pH}$ is an important physico-chemical factor regulating microbial activity in aquaponics systems, which must be kept within a range optimal for fish, plants, and bacteria (Zou et al. 2016). Nitrifying bacteria perform optimally at $\mathrm{pH}$ levels greater than 7.5, with inhibition of biological oxidation of $\mathrm{NH}_{4}{ }^{+}$occurring below pH 6.0 and above $\mathrm{pH}$ 9.0. Low $\mathrm{pH}$ ( $\mathrm{pH} 5.2$ to 6.0) negatively affects ammonia-oxidising bacteria (AOB) and nitrite-oxidising bacteria (NOB), decreases nitrification, enhances $\mathrm{N}_{2} \mathrm{O}$ emission, and causes stress to the fish in aquaponics systems (Ruiz et al. 2003; Sallenave 2016; Wongkiew et al. 2018; Zou et al. 2016). According to Somerville et al. (2014), the most common nitrifying bacteria in aquaponics are Nitrosomonas and Nitrobacter with their $\mathrm{pH}$ tolerance levels ranging from 7.2-7.8 and 7.2-8.2, respectively. Although it is not possible to achieve an optimum $\mathrm{pH}$ for fish, bacteria, and plants in aquaponics systems, a compromise between nitrification and nutrient availability is reached in aquaponics systems by maintaining $\mathrm{pH}$ values within the levels of 6.5-7.0 (Sallenave 2016; Somerville et al. 2014).

Wongkiew et al. (2017) reported a decrease in nitrification below $\mathrm{pH}$ 6.0. The influence of $\mathrm{pH}$ on bacterial populations in aquaponics systems is, however, not straight forward. For example, Wongkiew et al. (2018) reported that in biofilters at $\mathrm{pH} 6.8-7.0$, Fusobacteria 
dominated over Acidobacteria, but this abundance was reversed in plant roots at the same $\mathrm{pH}$. However, at $\mathrm{pH} 5.2$, the relative abundance of Acidobacteria decreased in the root samples, which were dominated by Proteobacteria.

\section{Water temperature}

Water temperature in aquaponics systems is important for optimal fish, plant, and microbial growth and health (Somerville et al. 2014). The DO content is a function of water temperature. Increasing water temperature also increases the percentage of TAN in water and increases cellular metabolism (Somerville et al. 2014). Although the optimal growth temperature for most nitrifiers ranges between 25 and $30^{\circ} \mathrm{C}, \mathrm{AOB}$ populations increase faster than NOB within this temperature range (Sallenave 2016; Tyson et al. 2011). Changes in temperature affect the efficiency of nitrification. Research by Head and Oleszkiewicz (2004) on the impact of rapid temperature changes from 20 to $10{ }^{\circ} \mathrm{C}$ showed an average decrease of $58 \%$ in the nitrification rate. In addition, variation in temperature influences microbial dynamics in nitrogen removal systems (Karkman et al. 2011; Urakawa et al. 2008). Karkman et al. (2011) reported that the genera Nitrosomonas and Nitrospira were dominant at $10{ }^{\circ} \mathrm{C}$ and that Nitrosospira dominated at $5{ }^{\circ} \mathrm{C}$, thus suggesting Nitrosospira might be more resistant to low temperature stress conditions.

\section{Dissolved oxygen}

Efficient nitrification is dependent on the dissolved oxygen (DO) content of the water (Rakocy et al. 2006). In aquaponics, DO is commonly controlled via aeration. Maintaining DO levels above $5 \mathrm{mg} \mathrm{L}^{-1}$ in aquaponics systems is vital, not only for activity of many microorganisms, but also for fish and plant health and growth. Maintaining DO concentrations of $5 \mathrm{mg} \mathrm{L}^{-1}$ is also of importance in systems with high densities of fish (Sallenave 2016). The DO concentration decreases in aquaponics systems because of the metabolic activity of aerobic microorganisms and the fish. Insufficient DO levels affect root respiration, which eventually decreases water and nutrient uptake and can lead to the loss of root cell tissue, thus promoting the development of plant root pathogens (Rakocy et al. 2006). The effect of DO levels on microbial activity has not yet been reported in aquaponics systems. However, studies using synthetic wastewater have shown activity of $\mathrm{AOB}$ and $\mathrm{NOB}$ to be sensitive to decreased DO levels, although the influence of free ammonia was more substantial on NOB inhibition at levels as low as $0.1 \mathrm{mg} \mathrm{L}^{-1} \mathrm{~N}$ (Kim et al. 2005). In systems with inadequate aeration and sludge buildup, anaerobic bacteria such as sulphate reducing bacteria, may dominate and produce toxic metabolites (Somerville et al. 2014).

\section{Carbon-to-nitrogen ratio}

The $\mathrm{C} / \mathrm{N}$ ratio in the water of aquaculture systems affects the structure and function of bacterial communities in these systems (Ballinger et al. 2002; Michaud et al. 2014; Xu et al. 2016; Zheng et al. 2018). Because of a slow maximum growth rate, nitrifying bacteria, which are autotrophic, are produced in lower quantities than heterotrophic bacteria (Ebeling et al. 2006). In the presence of organic carbon, TAN removal can substantially decrease (Ebeling et al. 2006 reported $\mathrm{NH}_{4}{ }^{+}$removal decreased by $90 \%$ at a $\mathrm{C} / \mathrm{N}$ ratio of 6 ). Increased heterotrophic assimilation pathways inhibit the nitrifying process and result in lower $\mathrm{NO}_{3}{ }^{-}$production $(\mathrm{Xu}$ et al. 2016; Ebeling et al. 2006; Zhu and Chen 2001). High C/ $\mathrm{N}$ ratios in the biofilter lead to an increase in heterotrophic bacteria, which then out-compete and dominate autotrophic nitrifying bacteria. Therefore, managing levels of organic carbon and control of DO levels is required to keep populations balanced (Joyce et al. 2019).

$\beta$-Proteobacterial autotrophic AOB communities in a bioreactor with denitrification and nitrification were reported by Ballinger et al. (2002). Increasing the influent $\mathrm{C} / \mathrm{N}$ ratio from 2 to 5 decreased nitrification rates by $50 \%$. Zheng et al. (2018) demonstrated changes to bacterial communities at phylum and genus levels at higher $\mathrm{C} / \mathrm{N}$ ratios. Their data showed an increase in the relative abundance of chemoheterotrophs, suggesting higher $\mathrm{C} /$ $\mathrm{N}$ ratios benefited the growth of heterotrophic bacteria. In aquaponics, heterotrophic bacteria utilise dissolved organic carbon of fish waste under aerobic conditions (Wongkiew et al. 2017).

\section{Specific surface area of the media}

The specific surface area (SSA) ratio is defined as the "exposed surface area to a given volume of media", expressed as $\mathrm{m}^{2} / \mathrm{m}^{3}$ (Somerville et al. 2014). A high SSA biofiltration material allows for the establishment of extensive colonies of nitrifying bacteria (DeLong and Losordo 2012). Smaller and more porous media particles provide a relatively large surface area for bacterial colonisation. The media matrix (e.g. volcanic gravel) of media grow beds provide support for plant roots to establish, and function as the substrate for biofiltration (Somerville et al. 2014; Zou et al. 2016).

\section{Plant type and growth characteristics}

Growth characteristics and nitrogen utilisation capacity differ depending on the plant species (Hu et al. 2015). In particular, root surface area is important for developing the nitrifying biofilm through the production of exopolymers to shield the bacteria from the external environment. Thus, plants with a large root surface area may provide an advantage for bacterial growth in an aquaponics system. $\mathrm{Hu}$ et al. (2015) reported that large root 
surface areas provide ideal habitats for nitrifying bacteria in aquaponics systems. Their research showed that the abundance of NOB was 4.4 times higher in tomato than in pak choi. These differences were attributed to the higher tomato plant root surface area whereby $99.8 \%$ of $\mathrm{AOB}$ and $99.9 \%$ of $\mathrm{NOB}$ were attached to the tomato root surface compared to $96.3 \%$ of $\mathrm{AOB}$ and $75.4 \%$ of $\mathrm{NOB}$ in pak choi (percentages relative to aquaponics water).

Root health is essential for plant health and survival and to the composition of microbial populations proximate to the root surface (Chagas et al. 2018). A $16 \mathrm{~S}$ rRNA meta-barcoding study of lettuce roots by Schmautz et al. (2017) revealed the genera Acidovorax, Sphingobium, Flavobacterium, and Pseudomonas in an aquaponics system integrated with Oreochromis niloticus and lettuce. However, the role of these bacteria on roots, including the effect of root exudates in aquaponics systems, is not yet known. Nevertheless, findings reported from research in traditional soil-based agriculture indicate that plant roots produce, accumulate and release an array of compounds, including organic acids, phenolics, nucleotides, carbohydrates, putrescine, sterols, and vitamins (Chagas et al. 2018; Michalet et al. 2013). Secreted compounds can act as both chemical attractants and repellents for microorganisms (Kawasaki et al. 2016).

\section{Hydraulic loading rate}

Within the context of aquaponics, hydraulic loading rate (HLR) is the "liquid flow rate per unit surface area of a grow bed" (Wongkiew et al. 2017) and it is expressed as $\mathrm{m}^{3} / \mathrm{m}^{2} /$ day $\left(\mathrm{m} \mathrm{day}^{-1}\right)$. Although HLR dictates optimum contact time for nutrient and microbe interaction with plant roots (Wongkiew et al. 2017), very few studies have reported on the effects of HLR on microbial ecology and diversity in aquaponics. The major focus has been on optimising HLR for water quality, as well as plant and fish growth and health (Endut et al. 2010; Shete et al. 2016; Yang and Kim 2020). Endut et al. (2010) compared five HLRs ranging between 0.64 and $3.20 \mathrm{~m} \mathrm{day}^{-1}$ and reported an optimal HLR for fish production, plant growth, and nutrient removal of $1.28 \mathrm{~m} \mathrm{day}^{-1}$. A high HLR decreases contact time between circulating water and plant roots and removes microbes and sediment associated with the plant roots (Endut et al. 2010).

\section{Additional influencers Algae}

Algae in aquaponics affect $\mathrm{pH}$, dissolved oxygen (DO), and TAN levels (Somerville et al. 2014). Algae commonly occur in aquaponics systems but are normally controlled by varying the diurnal temperature, photoperiod, and light intensity (Ramanan et al. 2015; Somerville et al. 2014). Their relative abundance in aquaponics systems may be an indication of excess nutrients in the system (nutrients not utilised by the plants). Welldocumented algal species involved in nitrogen and phosphorus removal are Scenedesmus, Chlorella, and Spirulina (Xin et al. 2010). Algae cause diurnal pH and DO variations due to photosynthesis and respiration, respectively, and they are adaptable to different environments (Addy et al. 2017; Kotzen et al. 2019). In aquaponics, algae may also block water pipes, attract insects, and negatively affect water quality (Kotzen et al. 2019; Somerville et al. 2014). Despite these negative effects, an experiment to evaluate the role of microalgae in the floating raft-aquaponics system showed that algae of the genera Chlorella spp. can remove nitrogen more efficiently than vegetables (Addy et al. 2017). In addition, algae can utilise both $\mathrm{NO}_{3}{ }^{-}$and $\mathrm{NH}_{4}{ }^{+}$(Xin et al. 2010). Thus, algae may play a unique role in aquaponics systems for nitrogen removal. In addition, evidence suggests a range of symbiotic relationships and interactions between microalgae and bacteria, which include mutualism, parasitism, and commensalism in aquatic ecosystems (Ramanan et al. 2015). Microalgae-bacteria interactions are species specific involving different metabolites, molecular signals, and transporters. With mutualistic association, heterotrophic bacteria have been reported to supply algae with the co-enzyme vitamin $\mathrm{B}_{12}$, while fixed carbon as dissolved organic matter is produced by algae (Ramanan et al. 2015). However, very few studies have reported on microalgae-bacteria interactions in aquaponics. Additionally, production of algae, especially in decoupled aquaponics systems, could provide a source of diet for the fish.

\section{Composting worms}

Composting worms can be used to control the build-up of organic solids in aquaponics gravel media beds. They assist in mineralising nutrients bound in the waste sediments, allowing the plants to access and metabolise these nutrients. As such, the addition of composting worms to an aquaponics system could influence the bacterial ecosystem by affecting nutrient availability to the microbiome. The growth rate of worms is partly influenced by a dark environment and moisture content, and these conditions in aquaponics are optimised by providing suitable quantities of media in the grow beds and flow rate adjustments, respectively (Wani and Mamta 2013; Kotzen et al. 2019). Flood- and drain-media beds are ideal because worms are not constantly under water. Aquaponics can be integrated with the production or farming of worms (vermiculture), thus creating a potential side-stream income. Aqueous extracts of vermicompost can improve plant growth, enhance beneficial microbial communities, improve nutrient availability to plants, and induce plant defence compounds synthesis 
(Pant et al. 2009; Wani and Mamta 2013), but their current applications in aquaponics are limited (Kotzen et al. 2019). Within the context of aquaponics, the need for the farming of earthworms was reported by Somerville et al. (2014), who documented the presence of "earthworms, isopods, amphipods, larvae and other small animals in aquaponics systems". For vermicomposting, Eisenia fetida and Eisenia andrei have been reported as suitable decomposers (Reinecke and Viljoen 1991). For instance, Haberman et al. (2015) reported an increase in iron and zinc in the nutrient solutions of aquaponics systems supplemented with red wiggler worms, Eisenia fetida.

\section{Conclusion and future perspectives}

The success of aquaponics as an alternative and/or supplement to traditional agriculture depends on a complex microbial ecosystem. The microbial ecosystem is key for biological filtration of water through the mineralisation of nutrients required for plant production in an integrated system. This review aims at offering the readers an update on the status of the information regarding the microbial composition of the aquaponics systems and some of the methods that have been used to characterise microbial diversity, as well as biochemical and metabolic activity. The efficient functioning of aquaponics biofilters originates from the diversity of microorganisms, and their ability to utilise the fish faeces in these ecosystems. Research showed that it is advantageous to establish a high-density population of the nitrifying bacteria in an aquaponics biofilter before introducing fish into the system.

Based on the literature reviewed, there is no evidence of the uptake of human food-borne pathogens in aquaponics-grown fruit and vegetables. There is however a critical need to optimise the operational parameters of the aquaponics systems and proper handling of aquaponics products post-harvest to prevent the proliferation of pathogens. This is needed to protect public health, considering most plants grown in aquaponics systems are consumed raw. Further research is needed on the role and interaction between earthworms and their role in aquaponics systems, and the bacterial/microbial composition of aquaponics systems.

Another knowledge gap that has emerged from this review is the mechanism(s) of inter-cell communication and interactions between bacteria in different compartments of an aquaponics system. Addressing this knowledge gap will likely contribute to an understanding of the potentials of microbes in the production of antimicrobial compounds and as potential biocontrol agents of plant pathogens. More research is also needed on the basic functioning of aquaponics systems, e.g. on the level of gene expression and the links to the productivity of aquaponics systems. The methods to play a crucial role will include meta-transcriptomic techniques. It will also be beneficial to apply techniques such as the nextgeneration sequencing to study genetic diversity and composition of aquaponics system under various operational sets of parameters.

Furthermore, it is necessary to perform assessments of the links between the staple diet in a given country and the potential use of aquaponics system to complement the diet. This is especially important in the context of identifying the types of nutrients that aquaponics could provide. Once this is done, studies will have to be conducted to include an assessment of microbial composition of aquaponics systems under potential conditions of crop rotation. In addition, aquaponics systems with multiple crop cultivation will have to be studied in the same context. Laboratory and pilot-scale studies will have to be conducted to investigate the links between crop rotation and staple food production, and the changes in microbial composition of aquaponics systems.

\section{Acknowledgements \\ The authors gratefully acknowledge funding from DAAD and Rhodes University.}

\section{Authors' contributions \\ All the authors collaborated for the completion of this work. NK designed and accomplished the first draft. BA provided valuable insights and suggestions for this article. HK and BW were involved in the initial writing and editing of the manuscript. The authors have all read and approved the final manuscript for publication.}

\section{Funding}

The work is part of the support of the DAAD scholarship programme for InRegion Rhodes University of South Africa, 2018. The programme is funded by Rhodes University and the German Federal Ministry of Economic Cooperation and Development (BMZ).

Availability of data and materials Not applicable

Ethics approval and consent to participate Not applicable

Consent for publication

All listed authors consented to the submission of this manuscript for publication

Competing interests

The authors declare no competing interests.

\section{Author details}

'Department of Biochemistry and Microbiology, Rhodes University, P.O. Box 94, Makhanda, Grahamstown 6140, South Africa. ${ }^{2}$ Animal Resources Research Programme, Abi Zonal Agricultural Research and Development Institute, National Agricultural Research Organisation, P.O. Box 219, Arua, Uganda. ${ }^{3}$ Department of Ichthyology and Fisheries Science, Rhodes University, P.O. Box 94, Makhanda, Grahamstown 6140, South Africa. 
Received: 18 September 2020 Accepted: 15 December 2020 Published online: 04 January 2021

\section{References}

Addy MM, Kabir F, Zhang R, Lu Q, Deng X, Current D, Griffith R, Ma Y, Zhou W, Chen P, Ruan R (2017) Co-cultivation of microalgae in aquaponic systems. Bioresour Technol 245:27-34

Aoi Y, Miyoshi T, Okamoto T, Tsuneda S, Hirata A, Kitayama A, Nagamune T (2000) Microbial ecology of nitrifying bacteria in wastewater treatment process examined by fluorescence in situ hybridization. J Biosci Bioeng 90: 234-240

Ballinger SJ, Head IM, Curtis TP, Godley AR (2002) The effect of C/N ratio on ammonia oxidising bacteria community structure in a laboratory nitrificationdenitrification reactor. Water Sci Technol 46:543-550

Bartelme RP, Oyserman BO, Blom JE, Sepulveda-Villet OJ, Newton RJ (2018) Stripping away the soil: plant growth promoting microbiology opportunities in aquaponics. Front Microbiol 9:8

Bartelme RP, Smith MC, Sepulveda-Villet OJ, Newton RJ (2019) Component microenvironments and system biogeography structure microorganism distributions in recirculating aquaculture and aquaponic systems. mSphere 4 : e00143-e00119

Biswas R, Sarkar A (2018) 'Omics' tools in soil microbiology: the state of the art. In: Adhya TK, Lal B, Mohapatra B, Paul D, Das S (eds) Advances in soil microbiology: recent trends and future prospects. Springer, Singapore, pp 35-64

Blancheton JP, Attramadal KJK, Michaud L, D'Orbcastel ER, Vadstein O (2013) Insight into bacterial population in aquaculture systems and its implication. Aquacult Eng 53:30-39

Brailo M, Schreier HJ, McDonald R, Maršić-Lučić J, Gavrilović A, Pećarević M, JugDujaković J (2019) Bacterial community analysis of marine recirculating aquaculture system bioreactors for complete nitrogen removal established from a commercial inoculum. Aquaculture 503:198-206

Chagas FO, Pessotti RC, Caraballo-Rodríguez AM, Pupo MT (2018) Chemical signaling involved in plant-microbe interactions. Chem Soc Rev 47:16521704

Chitmanat C, Pimpimol T, Chaibu P (2015) Investigation of bacteria and fish pathogenic bacteria found in freshwater aquaponic system. J Agric Sci 7: 254-259

da Silva CB, Fitzsimmons K (2016) Use of Bacillus spp. to enhance phosphorus availability and serve as a plant growth promoter in aquaponics systems. Sci Hortic 211:277-282

Daims H, Lebedeva EV, Pjevac P, Han P, Herbold C, Albertsen M, Jehmlich N, Palatinszky M, Vierheilig J, Bulaev A, Kirkegaard RH, von Bergen M, Rattei T, Bendinger B, Nielsen PH, Wagner M (2015) Complete nitrification by Nitrospira bacteria. Nature 528:555-559

Daskalov H (2006) The importance of Aeromonas hydrophila in food safety. Food Control 17:474-483

DeLong DP, Losordo TM (2012) How to start a biofilter. Southern Regional Aquaculture Center. SRAC Publication 4502:1-4

Ebeling JM, Timmons MB, Bisogni JJ (2006) Engineering analysis of the stoichiometry of photoautotrophic, autotrophic, and heterotrophic removal of ammonia-nitrogen in aquaculture systems. Aquaculture 257:346-358

Eck M, Sare AR, Massart S, Schmautz Z, Junge R, Smits THM, Jijakli MH (2019) Exploring bacterial communities in aquaponic systems. Water 11:260

Elumalai SD, Shaw AM, Pattillo DA, Currey CJ, Rosentrater KA, Xie K (2017) Influence of UV treatment on the food safety status of a model aquaponic system. Water 9:27

Endut A, Jusoh A, Ali N, Wan Nik WB, Hassan A (2010) A study on the optimal hydraulic loading rate and plant ratios in recirculation aquaponic system. Bioresour Technol 10:1511-1517

FAO/WHO (2008) Microbiological hazards in fresh leafy vegetables and herbs: meeting report. Microbiological Risk Assessment Series No. 14, Rome, pp 2-9 Available at: http://www.fao.org/3/a-i0452e.pdf (accessed on $7^{\text {th }}$ June 2020)

Fedoroff NV, Battisti DS, Beachy RN, Cooper PJM, Fischhoff DA, Hodges CN, Knauf VC, Lobell D, Mazur BJ, Molden D, Reynolds MP, Ronald PC, Rosegrant MW, Sanchez PA, Vonshak A, Zhu JK (2010) Radically rethinking agriculture for the $21^{\text {st }}$ Century. Science 327:833-834

Fox BK, Tamaru CS, Hollyer J, Castro LF, Fonseca JM, Jay-Russell M, Low T (2012) A preliminary study of microbial water quality related to food safety in recirculating aquaponic fish and vegetable production systems. College of Tropical Agriculture and Human Resources, University of
Hawaii at Manoa. Food Safety and Technology. FST 51:1-11 Available at: https:/www.ctahr.hawaii.edu/oc/freepubs/pdf/fst-51.pdf (accessed 7 June 2020)

Galloway-Pena J, Hanson B (2020) Tools for analysis of the microbiome. Dig Dis Sci 65:674-685

Goddek S, Joyce A, Wuertz S, Körnerlngo O, Bläser I, Reuter M, Keesman KJ (2019) Decoupled aquaponics systems. In: Goddek S, Joyce A, Kotzen B, Burnell G (eds) Aquaponics food production systems. Springer, Cham, Switzerland, pp 202-204

Goddek S, Schmautz Z, Scott B, Delaide B, Keesman KJ, Wuertz S, Junge R (2016) The effect of anaerobic and aerobic fish sludge supernatant on hydroponic lettuce. Agronomy 6:37

Gomes C, Da Silva P, Moreira RG, Castell-Perez E, Ellis EA, Pendleton M (2009) Understanding $E$. coli internalization in lettuce leaves for optimization of irradiation treatment. Int J Food Microbiol 135:238-247

Haberman A, Peterson M, Ruby A (2015) The effect of red wiggler worms (Eisenia fetida) on aquaponics nutrient solution properties and system stability across solution temperature. Retrieved from the University of Minnesota Digital Conservancy Available at: https://conservancy.umn.edu/ bitstream/handle/11299/172221/Allison\%20Ruby\%20Team\%202\%20Poster. pdf? sequence=|\&isAllowed $=y$ (accessed on 8 June 2020)

Hagopian DS, Riley JG (1998) A closer look at the bacteriology of nitrification. Aquacult Eng 18:223-244

Head MA, Oleszkiewicz JA (2004) Bioaugmentation for nitrification at cold temperatures. Water Res 38:523-530

Holmes DE, Dang Y, Smith JA (2019) Nitrogen cycling during wastewater treatment. Adv. Appl Microbiol 106:118-148

Hong CX, Moorman GW (2005) Plant pathogens in irrigation water: challenges and opportunities. Crit Rev Plant Sci 24:189-208

Hu Z, Lee JW, Chandran K, Kim S, Brotto AC, Khanal SK (2015) Effect of plant species on nitrogen recovery in aquaponics. Bioresour Technol 188:92-98

Joyce A, Timmons M, Goddek S, Pentz T (2019) Bacterial relationships in aquaponics: new research directions. In: Goddek S, Joyce A, Kotzen B, Burnell GM (eds) Aquaponics food production systems. Springer, Cham, Switzerland, pp 145-161

Karkman A, Mattila K, Tamminen M, Virt M (2011) Cold temperature decreases bacterial species richness in nitrogen-removing bioreactors treating inorganic mine waters. Biotechnol Bioeng 108:2876-2883

Kasozi N, Kaiser H, Wilhelmi B (2020) Metabarcoding analysis of bacterial communities associated with media grow bed zones in an aquaponic system. Int J Microbiol 2020:8884070

Kawasaki A, Donn S, Ryan PR, Mathesius U, Devilla R, Jones A, Watt M (2016) Microbiome and exudates of the root and rhizosphere of Brachypodium distachyon, a model for wheat. PLoS One 11:e0164533

Kim D-J, Ahn DH, Lee D-I (2005) Effects of free ammonia and dissolved oxygen on nitrification and nitrite accumulation in a biofilm airlift reactor. Korean J Chem Eng 22:85-90

Kotzen B, Emerenciano MGC, Moheimani N, Burnell GM (2019) Aquaponics: alternative types and approaches. In: Goddek S, Joyce A, Kotzen B, Burnell G (eds) Aquaponics food production systems. Springer, Cham, Switzerland, pp 301-310

Krom MD, Ellner S, Van Rijn J, Neori A (1995) Nitrogen and phosphorus cycling and transformations in a prototype 'non-polluting' integrated mariculture system. Eilat, Israel Mar Ecol Prog Ser 118:25-36

Lareen A, Burton F, Schäfer P (2016) Plant root-microbe communication in shaping root microbiomes. Plant Mol Biol 90:575-587

Lee S, Lee J (2015) Beneficial bacteria and fungi in hydroponic systems: types and characteristics of hydroponic food production methods. Sci Hortic 195: 206-215

Li M, Ishiguro Y, Otsubo K, Suzuki H, Tsuji T, Miyake N, Nagai H, Suga H, Kageyama K (2014) Monitoring by real-time PCR of three water-borne zoosporic Pythium species in potted flower and tomato greenhouses under hydroponic culture systems. Eur J Plant Pathol 140:229-242

Love DC, Fry JP, Li X, Hill ES, Genello L, Semmens K, Thompson RE (2015) Commercial aquaponics production and profitability: findings from an international survey. Aquaculture 435:67-74

Lu H, Chandran K, Stensel D (2014) Microbial ecology of denitrification in biological wastewater treatment. Water Res 64:237-254

Macarisin D, Patel J, Sharma VK (2014) Role of curli and plant cultivation conditions on Escherichia coli 0157:H7 internalization into spinach grown on hydroponics and in soil. Int J Food Microbiol 173:48-53 
Mehle N, Gutiérrez-aguirre I, Prezelj N, Delic D (2014) Survival and transmission of potato virus $Y$, Pepino Mosaic virus, and potato spindle tuber viroid in water. J Appl Environ Microbiol 80:1455-1462

Mehle N, Ravnikar M (2012) Plant viruses in aqueous environment: survival, water mediated transmission and detection. Water Res 46:4902-4917

Mendes R, Garbeva P, Raaijmakers JM (2013) The rhizosphere microbiome: significance of plant beneficial, plant pathogenic, and human pathogenic microorganisms. FEMS Microbiol Rev 37:634-663

Michalet S, Rohr J, Warshan D, Bardon C, Rogy J-C, Domenach A-M, Czarnes S, Pommier T, Combourieu B, Guillaumaud N, Bellvert F, Comte G, Poly F (2013) Phytochemical analysis of mature tree root exudates in situ and their role in shaping soil microbial communities in relation to tree $\mathrm{N}$-acquisition strategy. Plant Physiol Biochem 72:169-177

Michaud L, Giudice AL, Interdonato F, Triplet S, Ying L, Blancheton JP (2014) C/N ratio-induced structural shift of bacterial communities inside lab-scale aquaculture biofilters. Aquacult Eng 58:77-87

Molden AD (2007) Water for food, water for life: a comprehensive assessment of water management in agriculture. Earth scan and Colombo: International Water Management Institute, London, pp 9-15

Mori J, Smith R (2019) Transmission of waterborne fish and plant pathogens in aquaponics and their control with physical disinfection and filtration: a systematized review. Aquaculture 504:380-395

Moriarty MJ, Semmens K, Bissonnette GK, Jaczynski J (2018) Inactivation with UV radiation and internalization assessment of coliforms and Escherichia coli in aquaponically grown lettuce. LWT-Food Sci Technol 89:624-630

Munguia-Fragozo P, Alatorre-Jacome O, Rico-Garcia E, Torres-Pacheco I, CruzHernandez A, Ocampo-Velazquez RV, Garcia-Trejo JF, Guevara-Gonzalez RG (2015) Perspective for aquaponic systems: "omic" technologies for microbial community analysis. Biomed Res Int 2015:480386

Pajares S, Bohannan BJM (2016) Ecology of nitrogen fixing, nitrifying, and denitrifying microorganisms in tropical forest soils. Front Microbiol 7:1045

Pant A, Radovich TJK, Hue NV, Talcott ST, Krenek KA (2009) Vermicompost extracts influence growth, mineral nutrients, phytonutrients and antioxidant activity in Pak choi (Brassica rapa cv. Bonsai Chinensis group) grown under vermicompost and chemical fertilizer. J Sci Food Agric 89: 2383-2392

Paulsen IT, Press CM, Ravel J, Kobayashi DY, Myers GS, Mavrodi DV, DeBoy RT, Seshadri R, Ren Q, Madupu R, Dodson RJ, Durkin AS, Brinkac LM, Daugherty SC, Sullivan SA, Rosovitz MJ, Gwinn ML, Zhou L, Schneider DJ, Cartinhour SW, Nelson WC, Weidman J, Watkins K, Tran K, Khouri H, Pierson EA, Pierson LS III, Thomashow LS, Loper JE (2005) Complete genome sequence of the plant commensal Pseudomonas fluorescens Pf5. Nat Biotechnol 23:873-878

Plotnikova JM, Rahme LG, Ausubel FM (2000) Pathogenesis of the human opportunistic pathogen Pseudomonas aeruginosa PA14 in Arabidopsis. Plant Physiol 124:1766-1774

Punja ZK, Utkhede RS (2003) Using fungi and yeasts to manage vegetable crop diseases. Trends Biotechnol 21:400-407

Rakocy JE, Masser MP, Losordo TM (2006) Recirculating aquaculture tank production systems: aquaponics-integrating fish and plant culture. SRAC Publication 454:1-16

Ramanan R, Kim BH, Cho DH, Oh HM, Kim HS (2015) Algae-bacteria interactions: evolution, ecology and emerging applications. Biotechnol Adv 34:14-29

Reinecke AJ, Viljoen SA (1991) A comparison of the biology of Eisenia fetida and Eisenia andrei (Oligo-chaeta). Biol Fertil Soils 11:295-300

Richardson AE, Barea J-M, McNeill AM, Prigent-Combaret C (2009) Acquisition of phosphorus and nitrogen in the rhizosphere and plant growth promotion by microorganisms. Plant Soil 321:305-339

Roosta HR, Hamidpour M (2011) Effects of foliar application of some macro- and micro-nutrients on tomato plants in aquaponic and hydroponic systems. Sci Hortic 129:396-402

Ruiz G, Jeison D, Chamy R (2003) Nitrification with high nitrite accumulation for the treatment of wastewater with high ammonia concentration. Water Res 37:1371-1377

Rurangwa E, Verdegem MCJ (2015) Microorganisms in recirculating aquaculture systems and their management. Rev Aquac 7:117-130

Sallenave R (2016) Important water quality parameters in aquaponics systems. New Mexico State University. Circular 680:1-8

Sanchez FA, Vivian-Rogers VR, Urakawa H (2019) Tilapia recirculating aquaculture systems as a source of plant growth promoting bacteria. Aquac Res 50:20542065
Schmautz Z, Graber A, Jaenicke S, Goesmann A, Junge R, Smits THM (2017) Microbial diversity in different compartments of an aquaponics system. Arch Microbiol 199:613-620

Schreier HJ, Mirzoyan N, Saito K (2010) Microbial diversity of biological filters in recirculating aquaculture systems. Curr Opin Biotechnol 21:318-325

Shakya M, Lo C-C, Chain PSG (2019) Advances and challenges in metatranscriptomic analysis. Front Genet 10:904

Shaw LJ, Nicol GW, Smith Z, Fear J, Prosser Jl, Baggs EM (2006) Nitrosospira spp. can produce nitrous oxide via a nitrifier denitrification pathway. Environ Microbiol 8:214-222

Shete AP, Verma AK, Chadha NK, Prakash C, Peter RM, Ahmad I, Nuwansi KKT (2016) Optimization of hydraulic loading rate in aquaponic system with Common carp (Cyprinus carpio) and Mint (Mentha arvensis). Aquacult Eng 72: $53-57$

Shulaev V (2016) Metabolomics technology and bioinformatics. Brief Bioinform 7: 128-139

Sirakov I, Lutz M, Graber A, Mathis A, Staykov Y, Smits THM, Junge R (2016) Potential for combined biocontrol activity against fungal fish and plant pathogens by bacterial isolates from a model aquaponic system. Water 8:528

Sirsat SA, Neal JA (2013) Microbial profile of soil-free versus in-soil grown lettuce and intervention methodologies to combat pathogen surrogates and spoilage microorganisms on lettuce. Foods 2:488-498

Sivapalasingam S, Friedman CR, Cohen L, Tauxe RV (2004) Fresh produce: a growing cause of outbreaks of foodborne illness in the United States, 1973 through 1997. J Food Prot 67:2342-2353

Solomon CM, Collier JL, Berg GM, Gilbert PM (2010) Role of urea in microbial metabolism in aquatic systems: a biochemical and molecular review. Aquat Microb Ecol 59:67-88

Somerville C, Cohen M, Pantanella E, Stankus A, Lovatelli A (2014) Small-scale aquaponic food production: integrated fish and plant farming In: FAO U (eds) FAO Fisheries and Aquaculture Technical Paper. Rome, Italy, pp 1-262

Stein LY, Klotz MG (2016) The nitrogen cycle. Curr Biol 26:R94-R98

Stouvenakers G, Dapprich P, Massart S, Jijakli MH (2019) Plant pathogens and control strategies in aquaponics. In: Goddek S, Joyce A, Kotzen B, Burnell G (eds) Aquaponics food production systems. Springer, Cham, Switzerland, pp 353-371

Thomsen PF, Willerslev E (2015) Environmental DNA - an emerging tool in conservation for monitoring past and present biodiversity. Biol Conserv 183:4-18

Tyson RV, Treadwell DD, Simonne EH (2011) Opportunities and challenges to sustainability in aquaponic systems. HortTechnology 21:6-13

Urakawa H, Tajima Y, Numata Y, Tsuneda S (2008) Low temperature decreases the phylogenetic diversity of ammonia-oxidizing archaea and bacteria in aquarium biofiltration systems. Appl Environ Microbiol 74:894-900

van Rijn J, Tal Y, Schreier HJ (2006) Denitrification in recirculating systems: theory and applications. Aquacult Eng 34:364-376

Verschuere L, Rombaut G, Sorgeloos P, Verstraete W (2000) Probiotic bacteria as biological agents in aquaculture. Microbiol Mol Biol Rev 64:655-671

Wang Y, Zhou Y, Xiao X, Zheng J, Zhou H (2020) Metaproteomics: a strategy to study the taxonomy and functionality of the gut microbiota. J Proteomics 219:1-11

Wani KA, Mamta RRJ (2013) Bioconversion of garden waste, kitchen waste and cow dung into value-added products using earthworm Eisenia fetida. Saudi J Biol Sci 20:149-154

WHO (1989) Health guidelines for the use of wastewater in agriculture and aquaculture. Technical Report Series 778. WHO, Geneva, p 33

Wongkiew S, Hu Z, Chandran K, Lee JW, Khanal SK (2017) Aquaponic systems for sustainable resource recovery: linking nitrogen transformations to microbial communities. Aquacult Eng 76:9-19

Wongkiew S, Park MR, Chandran K, Khanal SK (2018) Aquaponic systems for sustainable resource recovery: linking nitrogen transformations to microbial communities. Environ Sci Technol 52:12728-12739

Xin L, Hong-ying H, Ke G, Jia Y (2010) Growth and nutrient removal properties of a freshwater microalga Scenedesmus spp. LX1 under different kinds of nitrogen sources. Ecol Eng 36:379-381

Xu WJ, Morris TC, Samocha TM (2016) Effects of C/N ratio on biofloc development, water quality, and performance of Litopenaeus vanname juveniles in a biofloc-based, high-density, zero-exchange, outdoor tank system. Aquaculture 453:169-175

Yang T, Kim H-J (2020) Effects of hydraulic loading rate on spatial and temporal water quality characteristics and crop growth and yield in aquaponic systems. Horticulturae 6:9 
Zheng X, Zhang D, Qin J, Wang Y (2018) The effect of C/N ratio on bacterial community and water quality in a mussel-fish integrated system. Aquac Res 49:1699-1708

Zhu S, Chen S (2001) Effects of organic carbon on nitrification rate in fixed film biofilters. Aquacult Eng 25:1-11

Zou Y, Hu Z, Zhang J, Xie H, Guimbaud C, Fang Y (2016) Effects of pH on nitrogen transformations in media-based aquaponics. Bioresour Technol 210: $81-87$

Zumft WG (1997) Cell biology and molecular basis of denitrification. Microbio Mol Biol Rev 61:533-616

\section{Publisher's Note}

Springer Nature remains neutral with regard to jurisdictional claims in published maps and institutional affiliations.

Ready to submit your research? Choose BMC and benefit from:

- fast, convenient online submission

- thorough peer review by experienced researchers in your field

- rapid publication on acceptance

- support for research data, including large and complex data types

- gold Open Access which fosters wider collaboration and increased citations

- maximum visibility for your research: over $100 \mathrm{M}$ website views per year

At BMC, research is always in progress.

Learn more biomedcentral.com/submissions 